\title{
Influence of Somatic Cell Count and Breed on Capillary Electrophoretic Protein Profiles of Ewes' Milk: A Chemometric Study
}

\author{
J. M. Rodríguez-Nogales, ${ }^{*}$ A. M. Vivar-Quintana, $†$ and I. Revilla ${ }^{1}$ \\ ${ }^{*}$ Food Technology Area, University of Valladolid, E.T.S. de Ingenierías Agrarias, Avda. Madrid 57, 34004 Palencia, Spain \\ †Food Technology Area, University of Salamanca. E.P.S de Zamora, Avda. Requejo 33, 49022 Zamora, Spain
}

\begin{abstract}
Bulk tank ewe milk from the Assaf, Castellana, and Churra breeds categorized into 3 somatic cell count (SCC) groups $(<500,000 ; 1,000,000$ to $1,500,000$; and $>2,500,000$ cells $/ \mathrm{mL}$ ) was used to investigate changes in chemical composition and capillary electrophoresis protein profiles. The results obtained indicated that breed affected fat, protein, and total solids levels, and differences were also observed for the following milk proteins: $\beta-, \beta_{1^{-}}, \beta_{2^{-}}$, and $\alpha_{\mathrm{s} 1^{-}}$III-casein, $\alpha$-lactalbumin, and $\beta$-lactoglobulin. High SCC affected fat and protein contents and bacterial counts. The level of $\beta_{1^{-}}, \beta_{2^{-}}$, and $\alpha_{\mathrm{s} 1}$-I-casein, and $\alpha$-lactalbumin were significantly lower in milk with SCC scores $>2,500,000$ cells $/ \mathrm{mL}$. A preliminary study of the chemical, microbiological, and electrophoretic data was performed by cluster analysis and principal components analysis. Applying discriminant analysis, it was possible to group the milk samples according to breed and level of SCC, obtaining a prediction of 100 and $97 \%$ of the samples, respectively.
\end{abstract}

Key words: capillary electrophoresis, somatic cell count, casein, whey protein

\section{INTRODUCTION}

For several reasons, such as genetic and environmental factors, the chemical composition of ewe's milk varies considerably. Among such factors, breed has a high impact on milk composition (Barillet, 1985; Sakul and Boylan, 1992). In Spain, local breeds such as Castellana and Churra (mainly located in the region of Castilla y León) are now being replaced by more productive foreign breeds in an attempt to increase yields in the short term.

Sheep's milk is used almost exclusively for the production of cheese; some types of cheese are very well known for their high quality. Their origin and quality

Received September 12, 2006.

Accepted January 29, 2007.

${ }^{1}$ Corresponding author: irevilla@usal.es are often guaranteed by Designation of Origin such as the Zamorano cheese (BOE, 1993). Although Designation of Origin cheeses are usually more expensive on the consumer market, farmers do not receive a much higher price for the milk from breeds included in Designation of Origin regulations. Dairy factories set the price per liter according to the contents of fat, protein, bacteria, and SCC. Despite the lower quality of foreignbreed milk, farmers usually obtain higher incomes by producing more milk with foreign breeds. This has led many Spanish sheep breeders to replace local breeds with animals of the Assaf breed, which is one of the most important foreign breeds (Ugarte et al., 2001). One of the first nuclei of the Assaf breed was in Zamora and currently Assaf ewes represent $49 \%$ of milked ewes in Spain (Martínez et al., 1999). Foreign breeds tend to adapt to the local environment less well than the Churra and Castellana breeds and, because they require more time for milking and more careful management, a greater incidence of mastitis is usually observed (Gonzalez-Rodríguez et al., 1995; Gonzalo et al., 2005). Nevertheless, other studies have reported that breed does not affect milk SCC (Fthenakis, 1996).

Somatic cell counts are often used to differentiate between healthy and infected mammary glands and are increasingly used in routine dairy sheep milk testing procedures as an indicator of flock udder hygiene and health. Some studies have shown that an increase in SCC leads to a modification in the chemical composition of ewe's milk. Milk yield, fat content, TS, CN, and lactose amounts are negatively correlated with SCC, whereas total nitrogen, NPN, whey proteins, and $\mathrm{pH}$ are positively correlated with SCC (Pirisi et al., 2000; Leitner et al., 2003; Vivar-Quintana and Revilla, 2005). Indeed, milk from mastitic udders exhibits increased proteolytic activity compared with milk from healthy ewes (Albenzio et al., 2004).

Although much less is known about the effect of SCC on milk protein profiles, some studies have pointed out that $\alpha-\mathrm{CN}$ and $\beta$-CN percentages decrease when the SCC increases, whereas LA and Ig do not (Ali et al., 1980; Duranti et al., 1990). Nevertheless, other studies have reported a significant increase in whey proteins 
(Albenzio et al., 2004). No data regarding the correlation between SCC and capillary electrophoresis of ewes' milk proteins have been found in the literature.

In the present study the effects of 3 levels of SCC on the composition of ewes' milk and capillary electrophoretic protein profiles were determined, and the influence of breed on those parameters was studied. In previous work, multivariate statistical analysis has proven useful for detection of the most significant changes induced by each factor (breed or SCC) and the most representative factors or those factors which best differentiated the samples. In the present study, cluster analysis, principal component analysis (PCA), and discriminant analysis were applied to classify the samples according to the selected factors.

\section{MATERIALS AND METHODS}

\section{Raw Material}

Milk samples were taken from bulk milk in 3 SCC groups $(<500,000$ cells $/ \mathrm{mL}$; between $1,000,000$ and $1,500,000$ cells $/ \mathrm{mL}$, and $>2,500,000$ cell $\mathrm{s} / \mathrm{mL}$ ). The upper and lower limits were set according to the highest and lowest SCC values found in Zamora (Spain) throughout the year. Then, the groups were made up according to the recommendations of the Sheep Improvement Consortium (Castilla y León, Spain) veterinary service and previous works (Pirisi et al., 2000) reporting significant differences in milk quality and technological properties among these groups.

Raw ewes' milk was collected from 3 herds of Assaf sheep, 3 herds of the Churra breed, and 2 herds of the Castellana breed because it was not possible to find herds with SCC higher than 2,500,000 cells/mL owing to their higher resistance to mastitis (Gonzalo et al., 2005). All the herds were bred in Zamora (Spain) under identical husbandry systems and feeding regimens. During the autumn and winter, the herds were kept in stables, fed with concentrates composed of beetroot pulp, alfalfa, barley, corn, soy, and cotton, and were machine-milked. The differences in bulk tank SCC would be due to the differences in hygiene practices, which would bring about considerable differences in the prevalence of mammary infection and hence, SCC (Gonzalo et al., 2005).

The herds were selected on the basis of milk SCC recorded during the previous months, choosing herds that always showed SCC within the limits of each group. Lambing in these herds was concentrated in the autumn. Two samples were taken from each herd and these samples were collected in the same week. Milk samples (16) were collected from the first week of November until the first week of December. Month within herd is a relevant factor of variation in SCC; however, month as a variation factor not within herd is of little importance (Gonzalo et al., 2005).

\section{Milk Analysis}

On the day of collection, milk samples were submitted to the Analysis Service of the Interprofessional Dairy Laboratory of the Junta de Castilla y León, Spain (LILCYL, Palencia, Spain) and analyzed for fat, protein, and TS (MilkoScan; Foss Analytical, Hillerød, Denmark), SCC (Fossomatic Foss Analytical), and total bacterial counts (BactoScan, Foss Analytical).

\section{Capillary Electrophoresis of Milk Proteins}

Capillary electrophoresis was carried out according to the method proposed by Rodríguez-Nogales et al. (2005), using a Beckman P/ACE System 2050, controlled by System Gold Software data system, version 810 (Beckman Instruments, Fullerton, CA). Separations were performed using a fused-silica capillary column (eCap, Beckman Instruments) of $60 \mathrm{~cm} \times 50 \mu \mathrm{m}$ internal diameter ( $50 \mathrm{~cm}$ to the detector window). Sample solutions were injected for $5 \mathrm{~s}$ at $352 \mathrm{~kg} / \mathrm{m}^{2}$. The separations were conducted at constant voltage $(20 \mathrm{kV})$ and the separation temperature was kept constant $\left(30^{\circ} \mathrm{C}\right)$. Ultraviolet detection was performed at $214 \mathrm{~nm}$. Before each injection, the capillary was washed with $0.1 \mathrm{M} \mathrm{NaOH}$ (5 min), deionized water (5 min), and 1 $M \mathrm{HCl}$ (5 min), and equilibrated with the running buffer (5 min). The running buffer ( $50 \mathrm{~m} M$ ) was prepared by mixing $14.7 \mathrm{M} \mathrm{H}_{3} \mathrm{PO}_{4}(847 \mu \mathrm{L})$ and $0.05 \%$ hydroxypropylmethyl cellulose with $6 \mathrm{M}$ urea solution $(250 \mathrm{~mL})$; $\mathrm{pH}$ was adjusted to 3.0 with $2 \mathrm{M} \mathrm{NaOH}$. Ewes' milk was skimmed by low-speed centrifugation $(3,000 \times g$ for 20 min; 4K15 Sigma, Osterode, Germany). The sample solutions were prepared by dissolving $300 \mu \mathrm{L}$ of skim milk in $1 \mathrm{~mL}$ of sample buffer. Sample buffer ( $\mathrm{pH} 8)$ consisted of $10 \mathrm{mM} \mathrm{H}_{3} \mathrm{PO}_{4}, 8 \mathrm{M}$ urea, $10 \mathrm{~m} M$ dithiothreitol, and $1 \mathrm{~m} M$ lysine-tryptophan-lysine. The sample solutions were filtered through $0.20-\mu \mathrm{m}$ filters (Millex$\mathrm{GV}_{13}$, Millipore, Molsheim, France) before analysis by capillary electrophoresis. Each sample was analyzed 3 times $(n=3)$ by capillary electrophoresis and the average of the relative area of each peak was calculated.

\section{Data Treatment}

The data were analyzed by one-way ANOVA and the LSD Fisher test was used to discriminate one mean from another, with a probability $\alpha=0.05$. Pearson correlation coefficients among variables were also determined. Different pattern recognition tools such as cluster analysis, PCA, and linear discriminant analysis 
Table 1. Chemical composition, SCC, bacterial count, and protein fractions of ewes' milk from different breeds $^{1}$

\begin{tabular}{|c|c|c|c|}
\hline \multirow[b]{2}{*}{ Milk properties } & \multicolumn{3}{|c|}{ Breed } \\
\hline & $\begin{array}{c}\text { Assaf } \\
(\mathrm{n}=6)\end{array}$ & $\begin{array}{l}\text { Castellana } \\
\quad(\mathrm{n}=4)\end{array}$ & $\begin{array}{l}\text { Churra } \\
(\mathrm{n}=6)\end{array}$ \\
\hline Fat $(\%, w t / w t)$ & $6.83 \pm 0.14^{\mathrm{a}}$ & $7.85 \pm 0.18^{\mathrm{b}}$ & $6.83 \pm 0.14^{\mathrm{a}}$ \\
\hline Protein $(\%, w t / w t)$ & $5.30 \pm 0.07^{\mathrm{a}}$ & $6.07 \pm 0.08^{c}$ & $5.58 \pm 0.007^{\mathrm{b}}$ \\
\hline TS $(\%, w t / w t)$ & $17.73 \pm 0.16^{\mathrm{a}}$ & $19.50 \pm 0.19^{\mathrm{b}}$ & $18.21 \pm 0.16^{\mathrm{a}}$ \\
\hline Bacterial count (log cfu/mL) & $4.89 \pm 0.15^{\mathrm{a}}$ & $4.99 \pm 0.08^{\mathrm{a}}$ & $4.86 \pm 0.11^{\mathrm{a}}$ \\
\hline $\mathrm{SSC}(\log \mathrm{cell} / \mathrm{mL})$ & $6.02 \pm 0.09^{\mathrm{a}}$ & $5.77 \pm 0.09^{\mathrm{a}}$ & $5.98 \pm 0.08^{\mathrm{a}}$ \\
\hline$\beta_{1}-\mathrm{CN}^{2}$ & $319.4 \pm 18.4^{\mathrm{a}}$ & $391.0 \pm 35.1^{\mathrm{b}}$ & $329.4 \pm 15.4^{\mathrm{ab}}$ \\
\hline$\beta_{2}-\mathrm{CN}$ & $210.7 \pm 11.3^{\mathrm{a}}$ & $256.5 \pm 24.2^{\mathrm{b}}$ & $198.5 \pm 7.70^{\mathrm{a}}$ \\
\hline$\beta-\mathrm{CN}$ & $42.5 \pm 1.33^{\mathrm{ab}}$ & $54.6 \pm 8.6^{\mathrm{b}}$ & $32.9 \pm 2.31^{\mathrm{a}}$ \\
\hline$\alpha_{\mathrm{S} 1}-\mathrm{III}-\mathrm{CN}$ & $49.9 \pm 2.9^{\mathrm{a}}$ & $59.2 \pm 4.4^{\mathrm{a}}$ & $74.9 \pm 3.7^{\mathrm{b}}$ \\
\hline$\alpha_{\mathrm{S} 1}-\mathrm{II}-\mathrm{CN}$ & $131.5 \pm 9.1^{\mathrm{a}}$ & $137.4 \pm 11.3^{\mathrm{a}}$ & $138.3 \pm 4.16^{\mathrm{a}}$ \\
\hline$\alpha_{\mathrm{S} 1}$-I-CN & $99.5 \pm 3.5^{\mathrm{a}}$ & $101.6 \pm 8.3^{\mathrm{a}}$ & $87.9 \pm 6.6^{\mathrm{a}}$ \\
\hline$\kappa-\mathrm{CN}$ & $95.6 \pm 3.33^{\mathrm{a}}$ & $105.6 \pm 10.6^{\mathrm{a}}$ & $104.0 \pm 2.84^{\mathrm{a}}$ \\
\hline$\beta$-LG & $52.3 \pm 6.3^{\mathrm{b}}$ & $33.2 \pm 5.17^{\mathrm{a}}$ & $44.8 \pm 6.05^{\mathrm{ab}}$ \\
\hline$\alpha-\mathrm{LA}$ & $67.9 \pm 8.4^{\mathrm{b}}$ & $44.0 \pm 8.1^{\mathrm{a}}$ & $29.8 \pm 2.8^{\mathrm{a}}$ \\
\hline $\mathrm{CN}$ & $949.3 \pm 44.6^{\mathrm{a}}$ & $1,106 \pm 99^{\mathrm{a}}$ & $965.9 \pm 31.1^{\mathrm{a}}$ \\
\hline Whey proteins & $83.3 \pm 8.4^{\mathrm{b}}$ & $59.6 \pm 8.1^{\mathrm{a}}$ & $45.1 \pm 2.8^{\mathrm{a}}$ \\
\hline
\end{tabular}

${ }^{\mathrm{a}-\mathrm{c}}$ Means within a row with different superscripts differ significantly $(P<0.05)$.

${ }^{1}$ Presented values are expressed as the means \pm standard error.

${ }^{2}$ Values expressed as peak area per $0.1 \mathrm{~mL}$ of milk injected.

were used for data treatment. Ward's method was applied for cluster analysis. Somatic cell count and bacterial counts were converted into decimal logarithm for statistical analysis. All statistical analyses were performed using the Statgraphics Plus computer program for Windows 4.0 (Statistical Graphics, Rockville, MD).

\section{RESULTS AND DISCUSSION}

\section{Univariate Data Analysis}

The effect of dairy ewe breed on chemical composition, SCC, total bacterial counts, and capillary electrophoresis protein profiles was studied. Quantification of ewes' milk protein fractions by capillary electrophoresis presents the difficulty of selection of a suitable standard. Indeed, there is no certified reference material that could be used as a standard of ewe's milk proteins. Therefore, electrophoretic data are shown as peak areas per milliliter of milk.

The changes in the parameters assayed in the Assaf, Castellana, and Churra milks are summarized in Table 1. Typical capillary electrophoresis profiles of ewes' milk from the 3 breeds with the corresponding peaks of casein fractions ( $\beta-, \beta_{1^{-}}, \beta_{2^{-}}, \alpha_{\mathrm{s} 1^{-}}$I, $\alpha_{\mathrm{s} 1}$-II, $\alpha_{\mathrm{s} 1}$-III, and $\kappa$-CN) and whey proteins ( $\alpha$-LA and $\beta$-LG) are shown in Figure 1. The ANOVA performed on the milk data sets disclosed significant differences among the types of breed for fat, protein, and TS. Similar percentages of fat and TS from Assaf and Churra milks were found, with the greatest levels of these parameters found in the Castellana breed. The milk from the Castellana breed ewes had significantly higher percentages of proteins than the Assaf and Churra milks. From the results obtained with analysis of the capillary electrophoresis protein profiles, notable differences in the areas of $\beta$-, $\beta_{1^{-}}, \beta_{2^{-}}$, and $\alpha_{\mathrm{s} 1}$-III-CN, and $\alpha$-LA and $\beta$-LG were observed among the 3 breeds. The highest areas of $\beta-, \beta_{1^{-}}$, and $\beta_{2}$-CN were seen in the Castellana milk, whereas the highest area of $\alpha_{\mathrm{s} 1}$-III-CN was found for the Churra milk. The sum of the area of $\alpha$-LA and $\beta$-LG in Assaf was 28 and $45 \%$ higher than in Castellana and Churra milks, respectively. These observations must have been due to the breed because the milks analyzed were from herds from different farms with identical husbandry

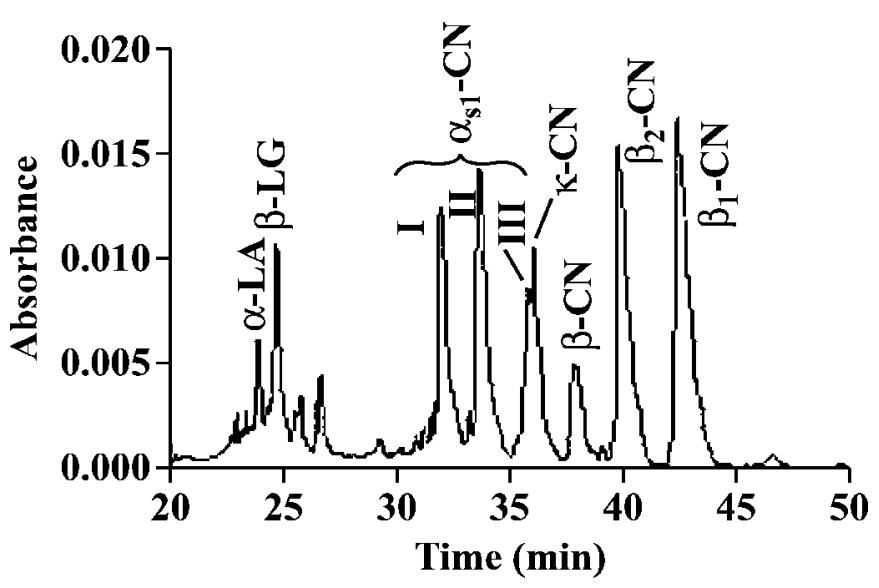

Figure 1. Capillary electrophoresis profile of proteins in ewes' milk. 
Table 2. Chemical composition, bacterial counts, and protein fractions of ewes' milk in different SCC groups ${ }^{1}$

\begin{tabular}{|c|c|c|c|}
\hline \multirow[b]{2}{*}{ Milk properties } & \multicolumn{3}{|c|}{$\mathrm{SCC}(\times 1,000 / \mathrm{mL})$} \\
\hline & $\begin{array}{l}<500 \\
(\mathrm{n}=6)\end{array}$ & $\begin{array}{c}1,000-1,500 \\
(\mathrm{n}=6)\end{array}$ & $\begin{array}{l}>2,500 \\
(\mathrm{n}=4)\end{array}$ \\
\hline Fat $(\%, w t / w t)$ & $7.49 \pm 0.16^{b}$ & $6.98 \pm 0.20^{\mathrm{a}}$ & $6.87 \pm 0.20^{\mathrm{a}}$ \\
\hline Protein $(\%$, wt/wt $)$ & $5.44 \pm 0.09^{\mathrm{a}}$ & $5.65 \pm 0.09^{\mathrm{ab}}$ & $5.77 \pm 0.12^{\mathrm{b}}$ \\
\hline $\mathrm{TS}(\%, \mathrm{wt} / \mathrm{wt})$ & $18.51 \pm 0.23^{\mathrm{a}}$ & $18.26 \pm 0.23^{\mathrm{a}}$ & $18.25 \pm 0.28^{\mathrm{a}}$ \\
\hline Bacterial count (log $\mathrm{cfu} / \mathrm{mL}$ ) & $4.58 \pm 0.07^{\mathrm{a}}$ & $5.11 \pm 0.08^{\mathrm{b}}$ & $5.04 \pm 0.06^{b}$ \\
\hline$\beta_{1}-\mathrm{CN}^{2}$ & $364.5 \pm 25.66^{\mathrm{b}}$ & $346.4 \pm 14.6^{\mathrm{ab}}$ & $279.81 \pm 19.3^{\mathrm{a}}$ \\
\hline$\beta_{2}-\mathrm{CN}$ & $221.6 \pm 14.6^{\mathrm{b}}$ & $235.3 \pm 12.1^{b}$ & $168.7 \pm 6.27^{\mathrm{a}}$ \\
\hline$\beta-\mathrm{CN}$ & $46.2 \pm 6.12^{\mathrm{a}}$ & $47.0 \pm 6.2^{\mathrm{a}}$ & $34.8 \pm 3.23^{\mathrm{a}}$ \\
\hline$\alpha_{\mathrm{S} 1}$-III-CN & $61.6 \pm 5.58^{\mathrm{a}}$ & $61.2 \pm 1.95^{\mathrm{a}}$ & $64.3 \pm 7.5^{\mathrm{a}}$ \\
\hline$\alpha_{\mathrm{S} 1}$-II-CN & $136.4 \pm 4.6^{\mathrm{a}}$ & $136.8 \pm 4.6^{\mathrm{a}}$ & $126.3 \pm 6.4^{\mathrm{a}}$ \\
\hline$\alpha_{\mathrm{S} 1}-\mathrm{I}-\mathrm{CN}$ & $94.8 \pm 5.39^{b}$ & $105.5 \pm 5.5^{\mathrm{b}}$ & $74.9 \pm 2.3^{\mathrm{a}}$ \\
\hline$\kappa$-CN & $103.4 \pm 6.51^{\mathrm{a}}$ & $103.8 \pm 3.42^{\mathrm{a}}$ & $91.1 \pm 3.9^{\mathrm{a}}$ \\
\hline$\beta$-LG & $46.2 \pm 6.1^{\mathrm{a}}$ & $47.0 \pm 6.2^{\mathrm{a}}$ & $34.8 \pm 3.3^{\mathrm{a}}$ \\
\hline$\alpha$-LA & $61.6 \pm 9.3^{\mathrm{b}}$ & $59.3 \pm 3.6^{\mathrm{b}}$ & $32.3 \pm 4.8^{\mathrm{a}}$ \\
\hline $\mathrm{CN}$ & $1,031.2 \pm 64.0^{\mathrm{b}}$ & $1,031.9 \pm 38.3^{\mathrm{b}}$ & $833.9 \pm 38.8^{a}$ \\
\hline Whey proteins & $77.1 \pm 9.4^{\mathrm{b}}$ & $71.5 \pm 3.7^{b}$ & $47.8 \pm 4.8^{\mathrm{a}}$ \\
\hline
\end{tabular}

${ }^{\mathrm{a}, \mathrm{b}}$ Means within a row with different superscripts differ significantly $(P<0.05)$.

${ }^{1}$ Presented values are expressed as the means \pm standard error.

${ }^{2}$ Values expressed as peak area per $0.1 \mathrm{~mL}$ of milk injected.

practices and feeding regimens. On the other hand, the type of ewe breed did not significantly influence SCC and bacterial counts because of the experimental design, which included the same number of samples, the same SCC levels, and a broad range of SCC for all breeds.

The ewes' milks were divided into 3 groups according to the SCC. Table 2 summarizes the milk compositions, total bacterial counts, and areas of milk protein fractions for the 3 levels of SCC. An ANOVA was performed on the data matrix. Differences $(P>0.05)$ among the 3 groups were found for fat and proteins. We found a significant negative correlation between $\operatorname{logSCC}$ and fat $(r=-0.4054)$, indicating that the ewes' milk with a high SCC presented a low percentage of fat. The decrease in fat levels reported in this study is in agreement with the work of Jaeggi et al. (2003) and it has been suggested that this finding is due to a reduction in the level of fat synthesis. Other authors have found greater milk fat content in ewes suffering from infectious mastitis, which was attributed to a dilution effect due to the smaller volumes of milk yielded (Albenzio et al., 2002). In the latter case, the drop in milk production is much more pronounced than the reduction in the level of fat synthesized (Marti de Olives and Molina Pons, 1998). A positive and significant correlation between $\operatorname{logSCC}$ and protein was found $(\mathrm{r}=0.3323)$. A similar correlation has been reported for SwedishFriesian cow's milk ( $r=0.374$; Lindmark-Mansson et al., 2000). The results showed that SCC had a significant effect on the total protein content, which increased with SCC. A high SCC is generally accompanied by an enhanced influx of serum components from the extracel- lular fluid into the milk (Albenzio et al., 2005), which is of no relevance to the dairy industry. No significant correlation was found between logSCC and TS. This is not surprising, because the ewe's milk with an SCC $>2,500,000$ cells $/ \mathrm{mL}$ showed the lowest percentages of fat and the highest percentages of proteins.

A strong positive relation between logSCC and bacterial counts was observed $(\mathrm{r}=0.5751)$. The group of ewes' milks with low SCC values had low bacterial counts, whereas no significant differences were observed between the groups of ewes' milk with medium and high SCC values. These results suggest that SCC could be used as an indirect indicator of the hygiene quality of ewes' milk. Some authors (Gonzalez-Rodríguez et al., 1995; Las Heras et al., 1999; Leitner et al., 2001; Gonzalo et al., 2006) have reported similar results. The immune response to bacterial udder contamination increases the SCC to a much greater extent in sheep than in dairy cows (Leitner et al., 2003). Nevertheless, for goats, cell counts are more difficult to link to presumed infections than is the case with cow's and ewe's milks (Raynal-Ljutovac et al., 2005).

In the case of dairy sheep, almost all the milk is processed to make cheese, and hence any changes in DM, mainly the CN concentration, will strongly affect the industry (Leitner et al., 2003). Accordingly, it is essential to elucidate the effect of subclinical mastitis on $\mathrm{CN}$ or $\mathrm{CN}$ fraction concentration and not on total protein. No previous data regarding the correlation between SCC and the capillary electrophoresis profiles of ewes' milk proteins have been found in the literature. In the present study, the values of total $\mathrm{CN}$ were significantly lower in milk with an SCC $>2,500,000$ cells/ 
$\mathrm{mL}$. The decrease in the $\mathrm{CN}$ content with increasing SCC could be due to increased proteolysis. Several authors have found that milk with high SCC levels show increased proteolytic activity (Leitner et al., 2003) due to plasmin (Albenzio et al., 2004) or to other proteases derived from somatic cells (Kelly and Foley, 1997).

In the present work we found statically significant differences between the values of $\beta_{1^{-}}, \beta_{2^{-}}$, and $\alpha_{\mathrm{s} 1} \mathrm{I}-\mathrm{CN}$. These CN fractions were significantly lower for the milk with the highest SCC. Some studies addressing the proteolysis of cow's milk have suggested that $\beta$-CN undergoes a higher extent of hydrolysis by plasmin than $\alpha_{\mathrm{s} 1}-\mathrm{CN}$ (Kelly and Foley, 1997) because the CN micelle structure in milk affords $\alpha_{\mathrm{s} 1}-\mathrm{CN}$ a degree of protection against attack by plasmin (de Koning et al., 1985). Other authors have reported enhanced nonplasmin proteolytic activity due to elevated SCC, resulting in a higher degradation of $\alpha_{\mathrm{s} 1}-\mathrm{CN}$ than of $\beta$-CN (Albenzio et al., 2005). Regarding whey proteins, significant differences were only found for $\alpha$-LA. As a result, the ewes' milk with the highest SCC had the lowest area values for $\alpha$-LA. These results suggest that the slight increase in the percentage of protein observed in milks with high SCC may be due to the fact that the increase in the level of soluble proteins, other than $\alpha$-LA and $\beta$-LG, is more pronounced that the reduction in the level of $\mathrm{CN}$ due to enzymatic hydrolysis.

\section{Multivariate Analysis}

Although the differences observed in the means of some variables among ovine breeds and among groups of milks with different SCC levels may reveal some interesting features and enabling the differentiation among these groups, in this study, a suitable association of the samples plotting the variables in an $\mathrm{X}-\mathrm{Y}$ diagram was not possible. The amount and complexity of these data make use of chemometric tools necessary to fully extract the wealth of information. Three different multivariate methods (cluster analysis, PCA, and discriminant analysis) were applied to the chemical and electrophoretic data.

Cluster Analysis. Cluster analysis allows a clustering of variables on the basis of mutual correlations. For this analysis, data were normalized to zero mean and unit variance to avoid misclassifications arising from the different orders to magnitude of both numerical values and the variance of the variables determined. The results of the cluster analysis carried out for all variables are presented as a dendrogram in Figure 2. Two main clusters can be found. The first one contains 2 subclusters. One of these was formed by variables associated with the gross chemical composition of the milk (fat, TS, and total proteins). The association be- tween these parameters is in agreement with the high values of the correlation coefficients found for fat and total solids $(r=0.9125)$, for protein and TS $(r=0.7997)$, and, to a lesser extent, for protein and fat $(r=0.4863)$. The second subcluster was associated with milk hygiene quality (bacterial counts and SCC). The second cluster associated the peak area of the milk protein fractions, showing a short distance between the peak area of $\alpha$-LA and $\beta$-LG. Figure 3 shows the results of the cluster analysis performed on all the ewes' milks studied. At a distance of 450, 2 large clusters are observed. Cluster 1 contained all the samples of ewes' milk with SCC values $<500,000$ cells $/ \mathrm{mL}$ and 2 samples of Assaf ewes' milk with medium SCC values. The second cluster comprised samples of milk with medium and high SCC values. The presence of the well-defined clusters indicates that the chemical, microbiological, and electrophoretic parameters jointly have sufficient information to distinguish between ewes' milks with different SCC values.

PCA. Principal components analysis enables the study of the real dimension of our data set, retaining the maximum possible amount of variability present in the data. Table 3 shows the significant principal components (PC; eigen value greater than unity) and their loadings (coefficients expressing the contribution of the original variables to the factor). Graphic plotting of the results of PCA is very useful for detecting the possible association of samples, and for detecting the possible variables that are associated with the group formed. The first 4 PC explained 78.6\% of the variance contained in the original data. Principal component 1 explained $32.2 \%$ of the variance and had a positive contribution from $\alpha_{\mathrm{s} 1}$-II-CN and $\alpha_{\mathrm{s} 1}$-III-CN and, to a lesser extent, from $\kappa$-CN, protein, and TS. Principal component 1 also had a negative contribution from $\beta$-CN, one of the minor CN fractions in ewe's milk, and from $\alpha_{\mathrm{s} 1^{-}}$ I-CN. Principal component 2 explained $22.9 \%$ of the variance and had a strong positive contribution from $\alpha$-LA and $\beta$-LG and a negative contribution from $\beta_{1^{-}}$ and $\beta_{2}$-CN. Principal component 1 was mainly determined by fat, TS, and $\kappa$-CN. The PCA biplot of PC1 vs. PC2 can be seen in Figure 4. The PCA results agree with those obtained by cluster analysis, because the variables are grouped in a similar way by both multivariate analyses.

The scores of the samples on PC 1 and 2 are plotted in Figure 5. Groups of samples with common levels of SCC can be observed. Ewes' milk samples from the Castellana breed with low SCC levels (samples coded in the figure as C1) are clearly separated from the other samples and are characterized by high and positive PC 2 , thus pointing to the high contents of whey proteins and low values of $\beta_{1^{-}}$and $\beta_{2}$-CN. Similar behavior can 


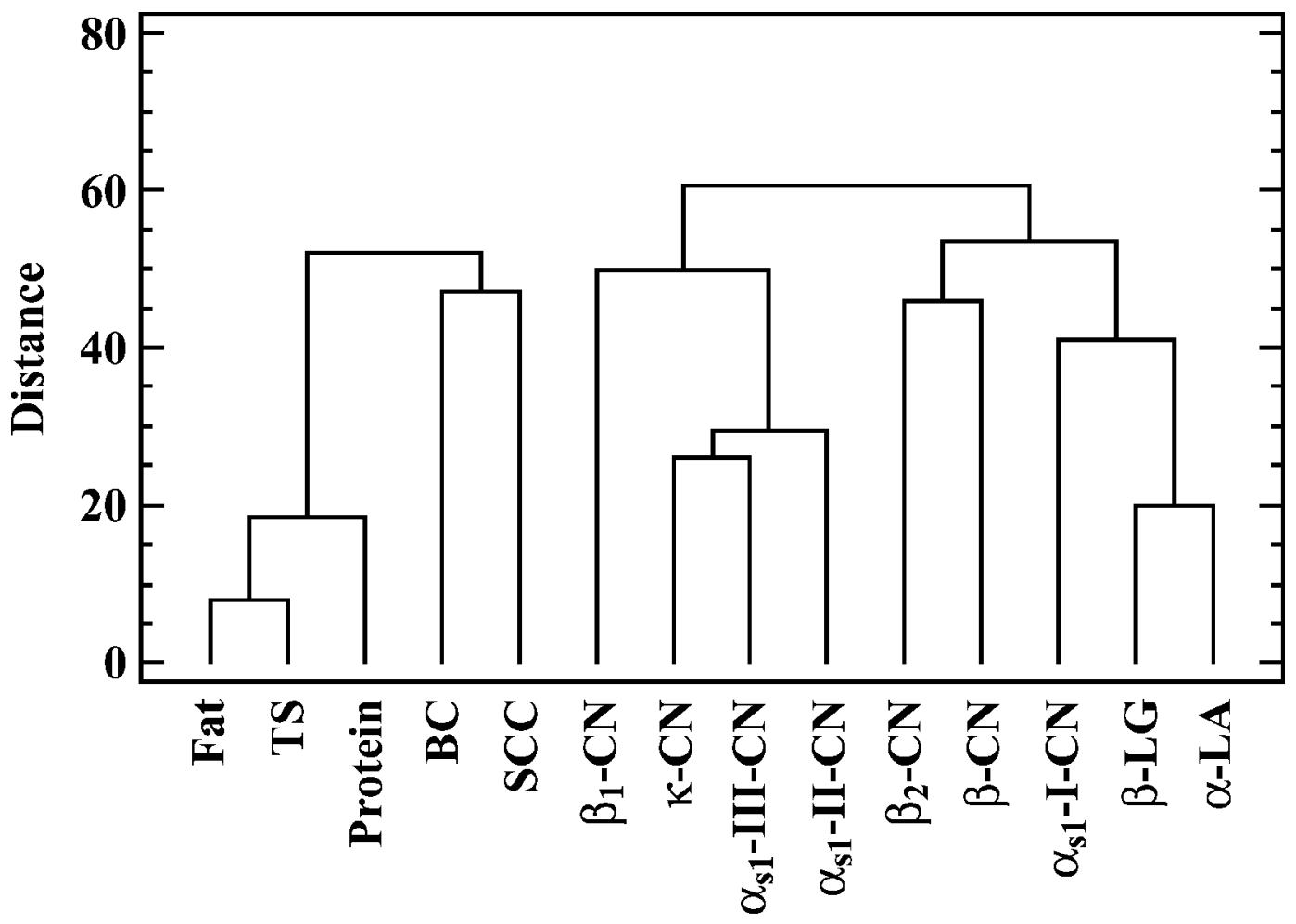

Variables

Figure 2. Dendrogram obtained with Ward's method applied to ewes' milks samples showing the variable associations. BC $=$ bacterial count.

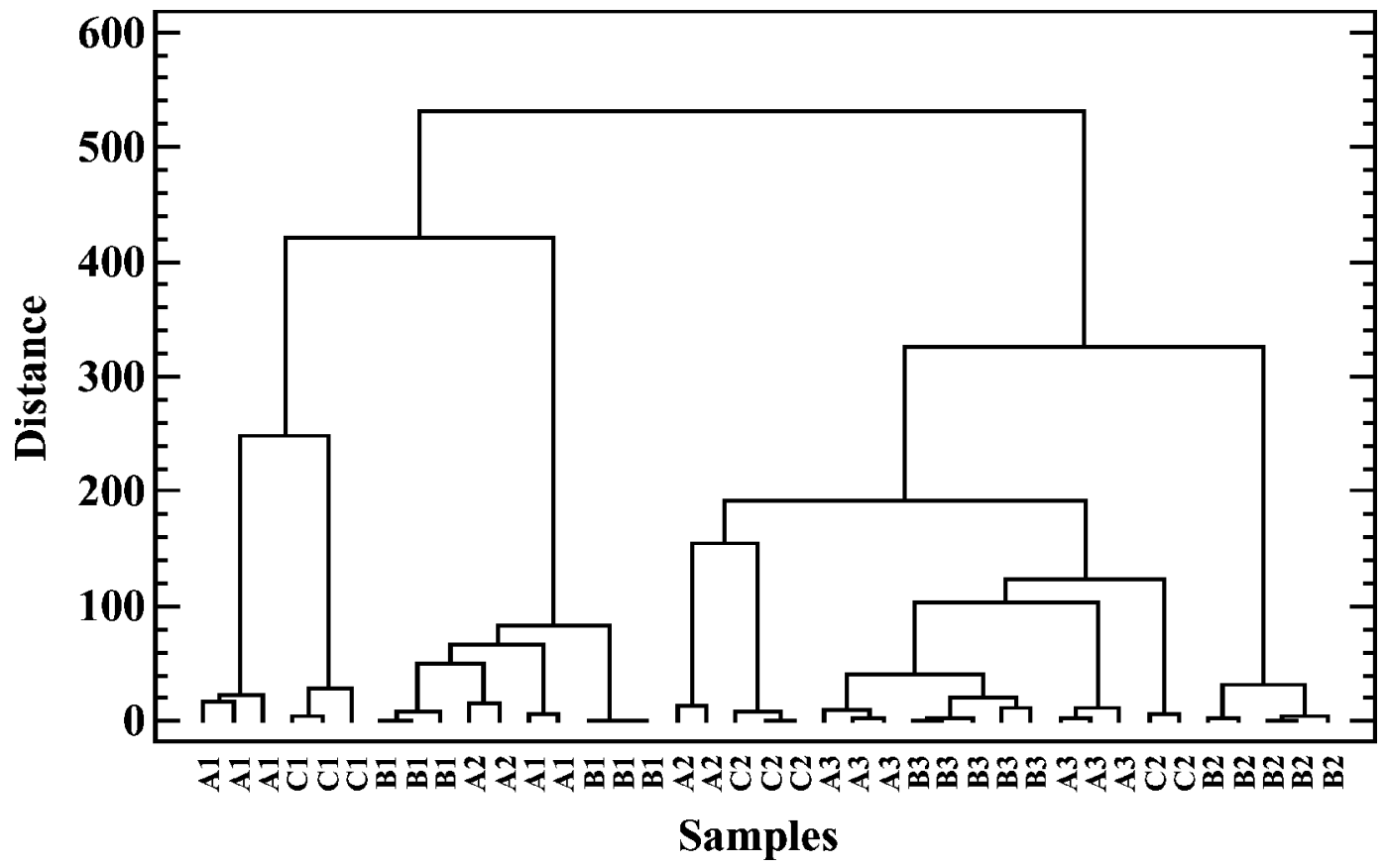

Figure 3. Dendrogram obtained with Ward's method applied to ewe's milks samples. A = Assaf breed; $\mathrm{B}=\mathrm{Churra}$ breed; $\mathrm{C}=\mathrm{Castellana}$ breed; $1=\mathrm{SCC}<500,000$ cells $/ \mathrm{mL} ; 2=\mathrm{SCC}$ of 1.0 to $1.5 \times 10^{6}$ cells $/ \mathrm{mL} ; 3=\mathrm{SCC}>2.5 \times 10^{6}$ cells $/ \mathrm{mL}$. 
Table 3. Factor loadings, eigenvalues, and variance of principal components (PC) $)^{1}$

\begin{tabular}{lcccc}
\hline & PC1 & PC2 & PC3 & PC4 \\
\hline Fat & - & 0.2802 & 0.4995 & - \\
Protein & 0.3086 & - & - & 0.3942 \\
TS & 0.2815 & 0.2945 & 0.3153 & 0.3242 \\
Bacterial count & - & - & - & - \\
$\beta_{1}$-CN & - & -0.4522 & 0.2755 & - \\
$\beta_{2}$-CN & - & -0.3066 & - & 0.5699 \\
$\beta$-CN & -0.3305 & - & - & - \\
$\kappa$-CN & 0.2964 & - & -0.3411 & - \\
$\alpha_{\text {S1-III-CN }}$ & 0.4121 & - & - & - \\
$\alpha_{\text {S1-II-CN }}$ & 0.3862 & - & - & - \\
$\alpha_{\text {S1-I-CN }}$ & -0.2595 & - & - & 0.3815 \\
$\beta$-LG & - & 0.4877 & - & - \\
$\alpha$-LA & - & 0.4092 & - & -0.2725 \\
Eigenvalue & 4.5068 & 3.2043 & 1.8620 & 1.4325 \\
Cumulative variance & 32.19 & 55.8 & 68.4 & 78.56 \\
\hline
\end{tabular}

${ }^{1}$ Loadings less than an absolute value of 0.250 are not shown.

be observed for milk samples from the Churra breed with medium SCC levels (coded as B2), but in this case the samples are related to high values of $\alpha_{\mathrm{s} 1}$-II- and $\alpha_{\mathrm{s} 1}$-III-CN and low values of $\beta_{2}$-CN. Assaf and Churra ewes' milks with high SCC values (coded as A3 and B3) are at the center of the diagram and show similar scores on both PC1 and PC2. Churra ewes' milk with low SCC values (coded as B1) is grouped and characterized by high levels of $\beta_{2}$-CN. However, the rest of the samples from the Assaf and Castellana breeds were not clearly classified, and hence a linear discriminant analysis (LDA) was performed.

LDA. In LDA the number of variables should be significantly less than that of the samples. Thus, the size of the data set was reduced to keep only the most important variables. For this analysis, a stepwise linear discriminant analysis was performed. This analysis has a forward option that begins with no variables in the model and adds them one at a time to obtain a final model.

A first classification based on the differences among breeds (Assaf, Castellana, and Churra) was performed. The most discriminating variables were selected based on the $P<0.05$ criterion. The final model was performed with the following variables: SCC, TS, $\beta-, \alpha_{\mathrm{s} 1}-\mathrm{I}-, \beta_{2^{-}}$, and $\alpha_{\mathrm{s} 1}$-III-CN, $\beta$-LG, protein, and fat, in order from greater to lesser discriminant power. In the 2-dimensional plot of the sample scores in the space defined by the 2 discriminant functions, separation of the ewes' milk samples into the 3 breeds was achieved (Figure 6). With this model an average training classification of $100 \%$ was achieved. The validation of the model was performed by exclusion of $25 \%$ of the samples 4 times, so that all the samples were predicted once. A prediction

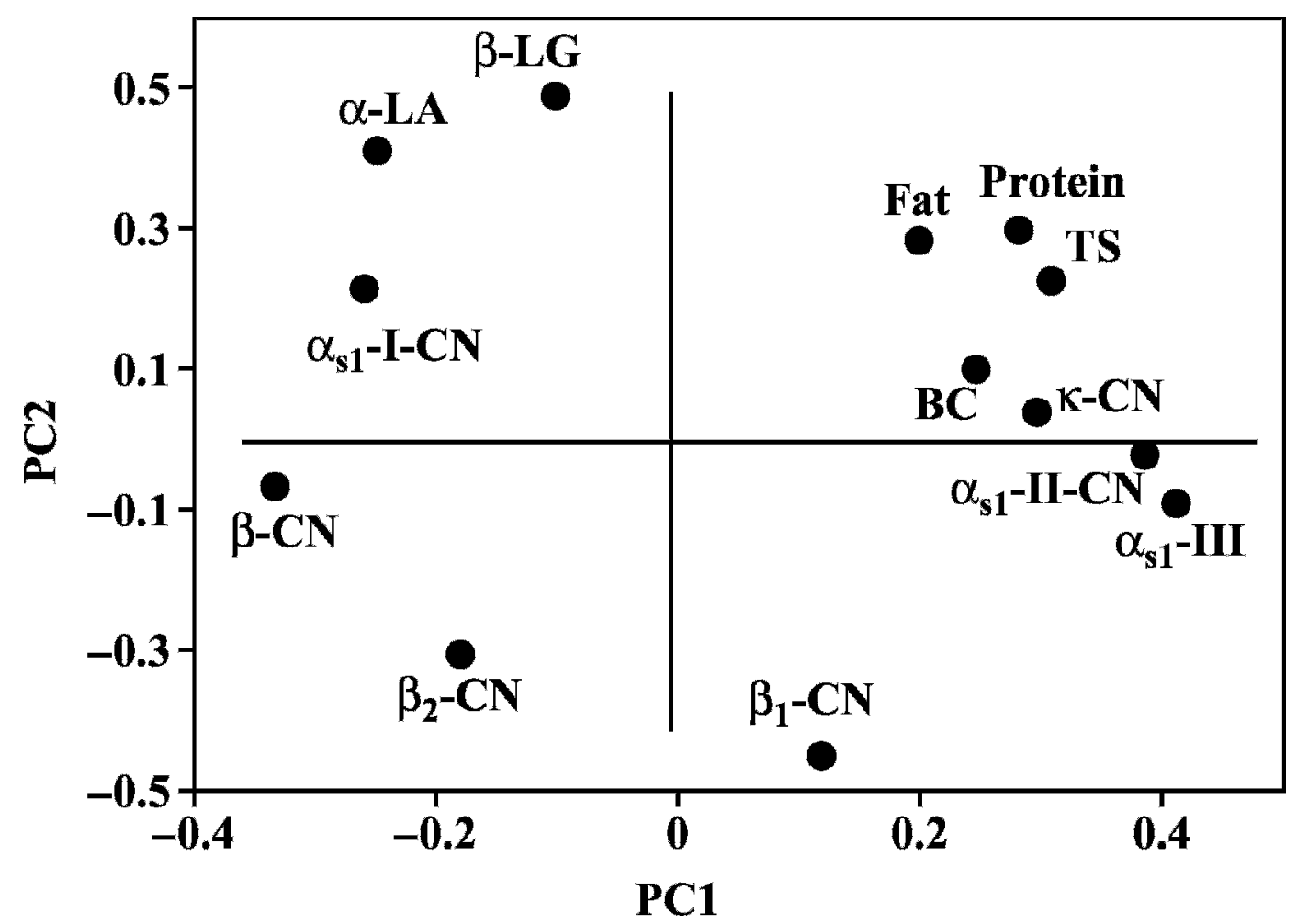

Figure 4. Scores of the variables on the first and second principal components $(\mathrm{PC}) \mathrm{BC}=$ bacterial count. 


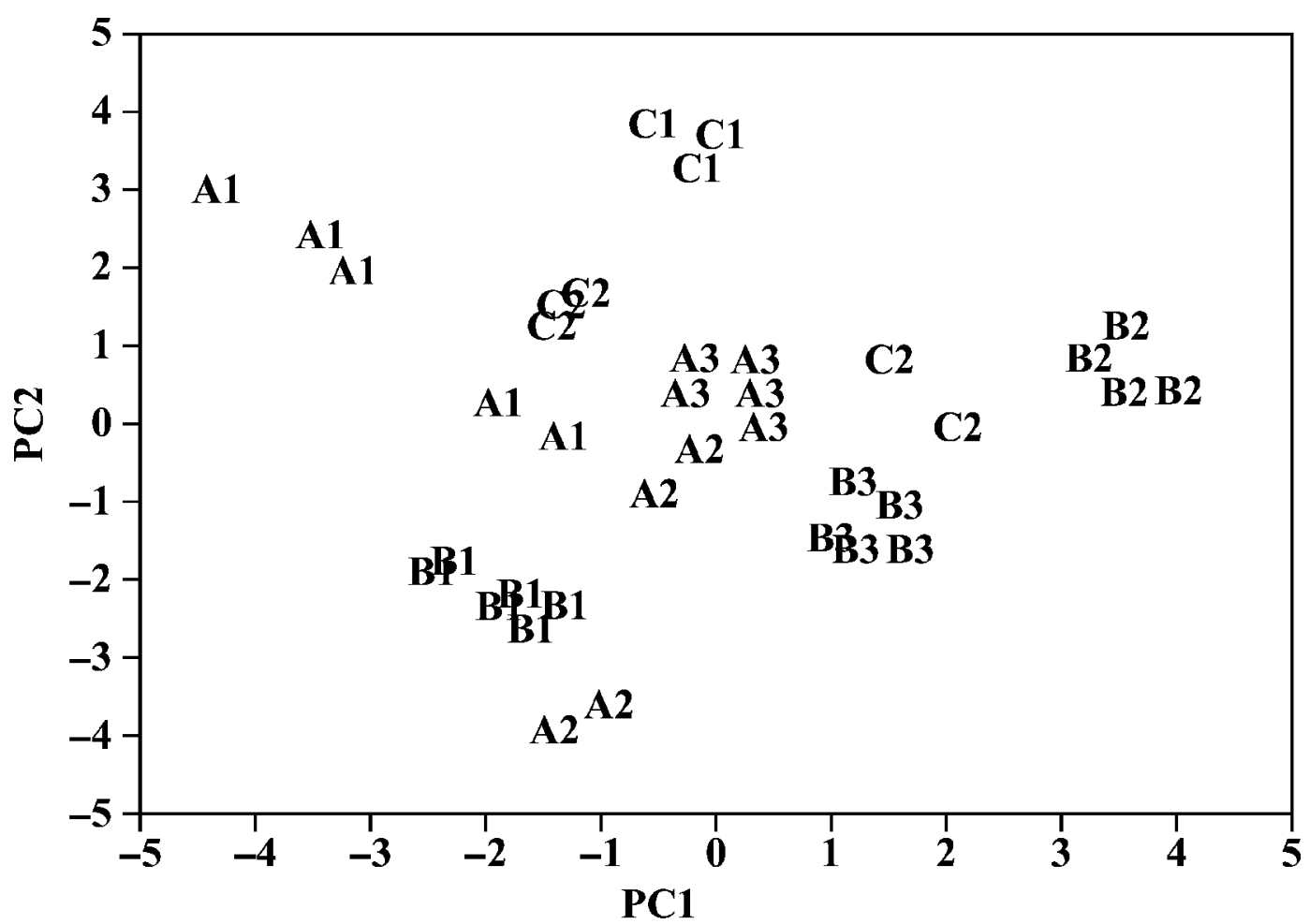

Figure 5. Scores of the ewes' milk samples on the first and second principal components $(\mathrm{PC}) . \mathrm{A}=\mathrm{Assaf}$ breed; $\mathrm{B}=\mathrm{Churra}$ breed; $\mathrm{C}=$ Castellana breed; $1=\mathrm{SCC}<500,000$ cells $/ \mathrm{mL} ; 2=\mathrm{SCC}$ of 1.0 to $1.5 \times 10^{6}$ cells $/ \mathrm{mL} ; 3=\mathrm{SCC}>2.5 \times 10^{6}$ cells $/ \mathrm{mL}$.

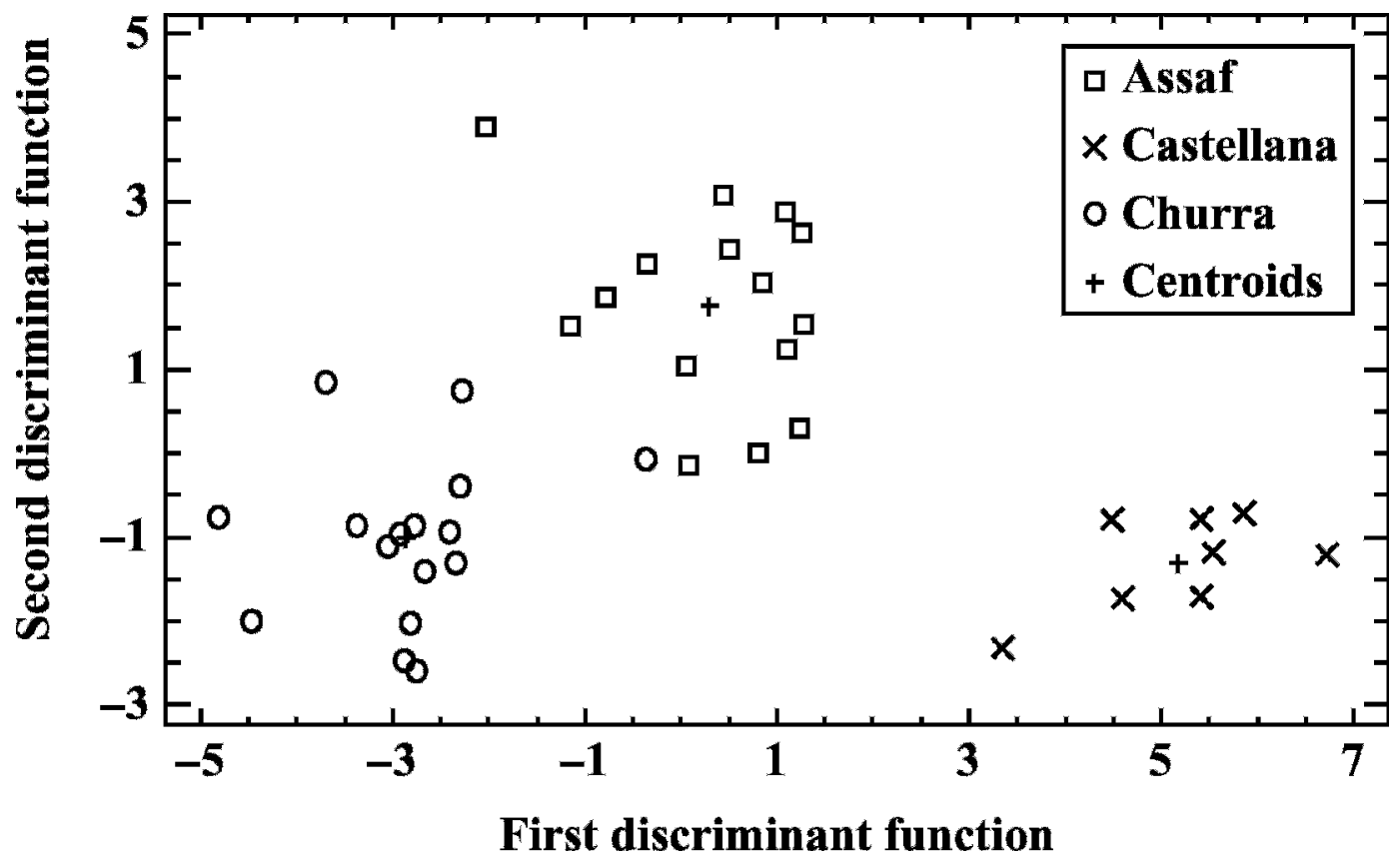

Figure 6. Scores of the ewes' milk samples classified in function of the type of breeds and represented on the first 2 discriminant functions. 


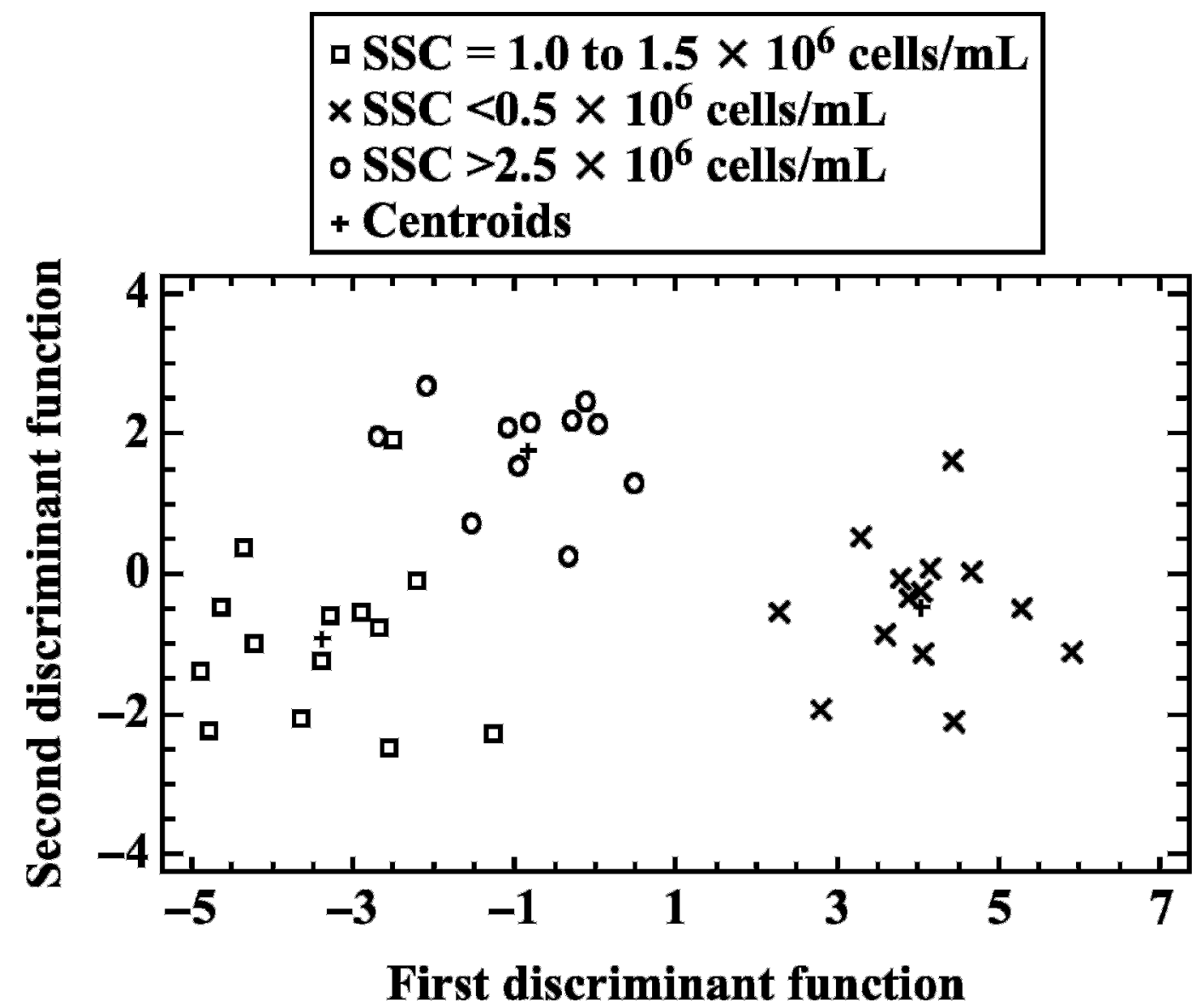

Figure 7. Scores of the ewes' milk samples classified in function of the range of SCC and represented on the first 2 discriminant functions.

rate of $94 \%$ was achieved, suggesting that the model presented may be a potential choice for checking the type of ovine breed.

A second classification was performed to classify the ewes' milks according the previously defined SCC groups. The final model selected the following 8 variables: $\alpha_{\mathrm{s} 1}$-III-CN, fat, bacteria count, $\beta$-LG, $\beta$-CN, $\alpha$ $\mathrm{LA}$, protein, and $\beta_{2^{-}} \mathrm{CN}$, in order from greater to lesser discriminant power. $\alpha_{\mathrm{s} 1}$-III-Casein, fat, and bacterial number had the highest $F$-value, so they were the most important variables for the differentiation of the ewes' milks from SCC. Using only these 3 variables, $80 \%$ correct classification was obtained. The results of the classification matrix of the model obtained showed an average training classification of $97.4 \%$. Only one milk sample from the Assaf breed with a medium SCC was incorrectly classified in the group of samples with SCC $>2,500,000 \mathrm{cell} / \mathrm{mL}$. The reliability of the prediction based on the variables selected was further tested by exclusion of $25 \%$ of the samples 4 times, and a global prediction of $96.2 \%$ was achieved. Figure 7 represents the plot of the milks in the plane defined by the 2 dis- criminant functions; a very good and clear separation is seen among 3 groups of milk with different SCC.

\section{CONCLUSIONS}

This study presents new information on the effect of SCC on the chemical composition, capillary electrophoresis protein profile, and hygiene quality of ewes' milk from different breeds. The results obtained here indicated that there were significant differences in gross milk composition (fat, protein, and TS) and capillary electrophoresis protein profiles among the 3 breeds. Indeed, fat, protein, bacterial number, total $\mathrm{CN}, \beta_{1^{-}}, \beta_{2^{-}}$, and $\alpha_{\mathrm{s} 1}$-I-CN, and $\alpha$-LA were significantly influenced by the SCC. The fat level was significantly higher for milks with lower SCC, and protein contents were significantly higher for milks with $>2,500,000$ cells $/ \mathrm{mL}$. The values of total $\mathrm{CN}, \beta_{1^{-}}, \beta_{2^{-}}$, and $\alpha_{\mathrm{s} 1}$-I-CN, and $\alpha$-LA were significantly lower for milk with SCC $>2,500,000$ cells $/ \mathrm{mL}$. These results are of special relevance for the production of cheese made from ewes' milk, because they suggest that the use of ewes' milk with SCC 
$>1,500,000$ cells $/ \mathrm{mL}$ should be avoided. Additionally, the results attained in this study allow us to conclude that the selected parameters provide adequate and sufficient information to differentiate milks according to the type of breed and SCC by multivariate analysis of the data.

\section{ACKNOWLEDGMENTS}

The authors are grateful to ASOVINO Cooperative and Spanish Junta de Castilla y León (SA066/04) for financial support.

\section{REFERENCES}

Albenzio, M., M. Caroprese, A. Santillo, R. Marino, A. Muscio, and A. Sevi. 2005. Proteolytic patterns and plasmin activity in ewe's milk as affected by somatic cell count and stage of lactation. J. Dairy Res. 72:86-92.

Albenzio, M., M. Caroprese, A. Santillo, R. Marino, L. Taibi, and A. Sevi. 2004. Effects of somatic cell count and stage of lactation on the plasmin activity and cheese-making properties of ewe milk. J. Dairy Sci. 87:533-542.

Albenzio, M., L. Taibi, A. Muscio, and A. Sevi. 2002. Prevalence and etiology of subclinical mastitis in intensively managed flocks and related changes in the yield and quality of ewe milk. Small Rumin. Res. 43:219-226.

Ali, A. E., A. T. Andrews, and G. C. Cheesman. 1980. Influence of elevated somatic cell count on casein distribution and cheesemaking. J. Dairy Res. 47:393-400.

BOE (Boletin Oficial del Estado). 1993. Order of 6-05-1993 of Ministry of Agriculture, Fish and Food that approves the Regulation board of Queso Zamorano Quality Appellation of Origin and the Regulation Council. Ministry of Agriculture, Fish and Food, Madrid, Spain.

Barillet, F. 1985. Amélioration génétique de la composition de lait des brebis. L'example de la race Lacaune. PhD Thesis. INRA, Paris-Grignon, France.

de Koning, P. J., J. Kaper, H. S. Rollema, and F. M. Driessen. 1985. Age-thinning and gelation in unconcentrated and concentrated UHT-sterilised skim milk. Effect of native milk proteinase. Neth. Milk Dairy J. 39:71-87.

Duranti, E., E. Casoli, and V. Vizioli. 1990. Composizione e qualità tecnologiche del latte di pecora di razza Massese. Pages $3-5$ in Atti IX Congreso Società Italiana di Patologia e di Allevamento degli Ovini e dei Caprini, Grado, Italy.

Fthenakis, C. G. 1996. Somatic cell counts in milk of Welsh Mountain, Dorset Horn and Chios ewes throughout the lactation. Small Rumin. Res 20:155-162.

Gonzalez-Rodríguez, C. M., C. Gonzalez, F. S. Primitivo, and P. Carmenes. 1995. Relationships between somatic cell count and intramammary infection of the half udder in dairy ewes. J. Dairy Sci. 78:2753-2759.

Gonzalo, C., J. A. Carriedo, E. Beneitez, M. T. Juárez, L. F. De la Fuente, and F. San Primitivo. 2006. Bulk tank total bacterial count in dairy sheep: Factors of variation and relationship with somatic cell count. J. Dairy Sci. 89:549-552.
Gonzalo, C., J. A. Carriedo, M. A. Blanco, E. Beneitez, M. T. Juárez, L. F. De la Fuente, and F. San Primitivo. 2005. Factors of variation influencing bulk tank somatic cell count in dairy sheep. J. Dairy Sci. 88:969-974.

Jaeggi, J. J., S. Govindasamy-Lucey, Y. M. Berger, M. E. Johnson, B. C. McKusick, D. L. Thomas, and W. L. Wendorff. 2003. Hard ewe's milk cheese manufactured from milk of three different groups of somatic cell counts. J. Dairy Sci. 86:3082-3089.

Kelly, A. L., and J. Foley. 1997. Proteolysis and storage stability of UHT milk as influenced by milk plasmin activity, plasmin/ $\beta$ lactoglobulin complexation, plasminogen activation and somatic cell count. Int. Dairy J. 7:411-420.

Las Heras, A., L. Dominguez, and J. F. Fernandez-Garayzabal. 1999. Prevalence and aetiology of subclinical mastitis in dairy ewes of the Madrid region. Small Rumin. Res. 32:21-29.

Leitner, G., M. Chaffer, Y. Caraso, E. Ezra, D. Kababea, M. Winkler, A. Glickman, and A. Saran. 2003. Udder infection and milk somatic cell count, NAGase activity and milk composition-fat, protein and lactose-in Israeli-Assaf and Awassi sheep. Small Rumin.Res. 49:157-164.

Leitner, G., M. Chaffer, S. Zamir, T. Mor, A. Glickman, M. Winkler, L. Weisblit, and A. Saran. 2001. Udder disease etiology, milk somatic cell count and NAGase activity in Israeli Assaf sheep throughout lactation. Small Rumin. Res. 39:107-112.

Lindmark-Mansson, H., U. Svensson, M. Paulsson, G. Alden, B. Frank, and G. Johnsson. 2000. Influence of milk components, somatic cells and supplemental zinc on milk processability. Int. Dairy J. 10:423-433.

Marti de Olives, A., and P. Molina Pons. 1998. Mamitis y calidad de leche de oveja. Ovis 59:11-25.

Martínez, R. S., A. Ruiz, M. D. Chico, L. Anel, M. M. Alvarez, J. J. Jurado, C. Díaz, J. Pérez, and N. Aparicio. 1999. Antecedentes históricos y bases de un programa de mejora genética y selección de la raza Assaf española. Consejo Superior de Investigaciones Científicas no. 37. Madrid, Spain.

Pirisi, A., G. Piredda, M. Corona, M. Pes, S. Pintus, and A. Ledda. 2000. Influence of somatic cell count on ewe's milk composition, cheese yield and cheese quality. Pages 47-59 in Proc. 6th Great Lakes Dairy Sheep Symposium, Ontario, Canada. D. L. Thomas and S. Porter, ed.

Raynal-Ljutovac, K., P. Gaborit, and A. Lauret. 2005. The relationship between quality criteria of goat milk, its technological properties and the quality of the final products. Small Rumin. Res. 60:167-177.

Rodríguez-Nogales, J. M., I. Revilla, and A. M. Vivar-Quintana. 2005. Experimental design applied for the simultaneous analysis of whey proteins and caseins of binary and ternary milk mixtures by capillary electrophoresis. J. Cap. Elec. Microchip Technol. 9:39-44.

Sakul, H., and W. J. Boylan. 1992. Evaluation of US sheep breeds for milk production and milk composition. Small Rumin. Res. 7:195-201.

Ugarte, E., R. Ruiz, D. Gabiña, and I. Beltrán de Heredia. 2001. Impact of high-yielding foreign breeds on the Spanish dairy sheep industry. Livest. Prod. Sci. 71:3-10.

Vivar-Quintana, A. M., and I. Revilla. 2005. Influencia de los recuentos en células somáticas sobre la composición de leche de oveja. Pages 353-356 in Proc. Avances de la Ciencia y Tecnología de los Alimentos en los inicios del siglo XXI. Servicio de Publicaciones Universidad de Burgos, Burgos, Spain. 